\title{
Leszek Kusak
}

Katedra Filozofii

Uniwersytet Ekonomiczny w Krakowie

\section{Antropologia elementarna Arnolda Gehlena}

\section{Streszczenie}

Artykuł ma charakter historyczno-komparatystyczny. Jego podstawowym celem jest rekonstrukcja głównych założeń, nieco już zapomnianej, antropologii filozoficznej Arnolda Gehlena. Niektóre z nich zaczerpnięte zostały z dzieł J.G. Herdera (człowiek jako Mängelwesen), F. Nietzschego (człowiek jako nicht festgestellte Tier) i M. Schelera („otwartość" człowieka na świat). Większość tez ma jednak charakter autorski (idea „odciążenia”, człowiek jako Kulturwesen, tradycja jako siła stabilizująca życie). Antropologia Gehlena ma, obok silnych stron, również pewne słabości (biologistyczna metafizyka, przywiązywanie zbyt dużej wagi do przestarzałej koncepcji ,istoty wykazującej braki”, zatarcie granic między metodą filozoficzną a metodą naukową). Są one przedmiotem dyskusji prowadzonych przez naukowców zajmujących się empirycznymi badaniami nad człowiekiem, jak i znawców filozofii człowieka. Ta kwestia jest również przedmiotem zainteresowania autora artykułu.

Słowa kluczowe: Mängelwesen, działanie, „otwartość” na świat, „odciążenie”, kultura, tradycja.

\section{Wprowadzenie}

Arnold Gehlen (1904-1976), obok Maxa Schelera (1874-1928) i Helmutha Plessnera (1892-1985), zaliczany jest do grona twórców nowoczesnej antropologii filozoficznej. Swoją główną pracę Der Mensch. Seine Natur und seine Stellung 
in der Welt opublikował w 1940 r. ${ }^{1}$ Przedstawił w niej oryginalną koncepcję człowieka, która wzbudziła duże zainteresowanie w świecie nauki i filozofii.

Prezentowany artykuł ma charakter historyczno-komparatystyczny. Jego podstawowym celem jest rekonstrukcja głównych założeń, nieco już obecnie zapomnianej, a wielu środowiskach w ogóle nieznanej, antropologii elementarnej Arnolda Gehlena. Antropologia ta, obok silnych stron, ma również pewne słabości, które nie uszły uwadze naukowców zajmujących się empirycznymi badaniami nad człowiekiem i znawców filozofii człowieka. Ta kwestia jest również przedmiotem zainteresowania autora artykułu.

\section{Gehlen a antropologia filozoficzna}

Koncepcja Gehlena osadzona jest w szerokich ramach projektu nowej dyscypliny filozoficznej, której założenia zostały sformułowane w latach dwudziestych XX w. przez Maxa Schelera. Wobec narastającego kryzysu filozoficznej refleksji nad człowiekiem, rozbieżności między teologicznym, filozoficznym i przyrodniczym ujęciem homo sapiens doszedł on do wniosku, że konieczne jest opracowanie nowego podejścia do badań nad człowiekiem, które dawałoby nadzieję na przełamanie dotychczasowego impasu ${ }^{2}$. Ucieleśnieniem tego projektu stała się antropologia filozoficzna rozumiana jako dyscyplina koncentrująca się na poszukiwaniu odpowiedzi na pytanie: „czym jest człowiek?” Pomysłodawca tej idei, Max Scheler, przyjął kilka ważnych założeń, z których dwa, jak się wydaje, odgrywają główną rolę i decydują o swoistości nowej dyscypliny.

Po pierwsze, idąc tropem Kanta, Scheler uznał, że ustalenia antropologii filozoficznej powinny stanowić podstawę i punkt odniesienia nie tylko dla innych dyscyplin filozoficznych, lecz także dla wszystkich nauk zajmujących się człowiekiem (biologia, psychologia, socjologia, językoznawstwo, neurologia itd.). Wszystkie ważne pytania z tego obszaru można (w pewnym sensie) sprowadzić do jednego, najważniejszego: „czym jest człowiek i jakie jest jego miejsce we wszechświecie?” Po drugie, przyjął on, że współczesnej, filozoficznej refleksji nad człowiekiem nie można rozwijać bez współpracy z nauką. Empiryczne

1 W 1962 r. ukazało się jej siedemnaste wydanie - ostatnie, które zostało przejrzane, poprawione i uzupełnione przez Gehlena. Uwzględnił w nim najnowsze wyniki badań poświęconych człowiekowi, dodał komentarze, dotyczące najczęściej formułowanych wobec jego koncepcji zarzutów i usunął niektóre, nazbyt polityczne ujęcia.

2 Komentując dotychczasowe próby naukowo-empirycznego ugruntowania filozoficznej koncepcji człowieka, Gehlen ocenia, że powiodły się one wyłącznie w odniesieniu do pewnych cech lub zespołów cech, ale nie w odniesieniu do „całego człowieka”. „Zadanie polegające na uchwyceniu «człowieka» jest bardzo trudne, było ono często podejmowane, jednak chyba jeszcze nigdy się nie udało" [Gehlen 1962, s. 12]. 
badania prowadzone w ramach szczegółowych nauk o człowieku muszą zostać uwzględnione w jego filozoficznej koncepcji. Poza dyskusją - zdaniem Schelera - pozostaje kwestia zagwarantowania autonomii filozofii i jej swoistych metod wobec nauki i metod naukowych, współpraca nie oznacza bowiem rezygnacji $\mathrm{z}$ wielowiekowego dorobku filozofii, ani też ograniczenia przedmiotu jej kompetencji.

Arnold Gehlen krytykował wprawdzie niektóre elementy koncepcji Schelera (np. dualistyczne ujęcie człowieka), jednak te dwa założenia nie są przez niego kontestowane. We „Wprowadzeniu” do Der Mensch Gehlen podkreśla, że tak jak możliwa jest anatomia, czyli ogólna nauka o budowie ludzkiego ciała, tak też możliwe jest ogólne ujęcie „człowieka” w ramach antropologii filozoficznej. Takie ujęcie - jego zdaniem - powinno stanowić punkt wyjścia i odniesienia dla każdej szczegółowej antropologii, dla psychologii, socjologii, jak i każdej innej nauki o człowieku, gdyż one tylko tematyzują pewne wybrane aspekty budowy i funkcjonowania człowieka, podczas gdy antropologia filozoficzna czyni swoim przedmiotem człowieka, całość fenomenu określanego mianem homo sapiens (zob. [Gehlen 1962, s. 11-12]).

Żadnych wątpliwości nie budził u Gehlena również postulat ścisłej współpracy filozofii z naukami szczegółowymi. Uprawiana przez niego antropologia elementarna jest pod każdym względem filozofią empiryczną, ,przetwarzającą wyniki badań wielu dyscyplin szczegółowych" [Gehlen 2001, s. 90]. Jej głównym zadaniem jest ,interpretacja zachowania realnego człowieka w realnym świecie”. Naukowość i zarazem filozoficzność antropologii elementarnej - w ujęciu Gehlena - polega na tym, że dokonuje ona przeglądu faktów z różnych nauk (biologia, morfologia, anatomia, fizjologia, psychologia, językoznawstwo, socjologia itd.), ale pod względem ogólnym, co właśnie jest zadaniem filozofii (zob. [Gehlen 1962, s. 14]).

Mocne zakorzenienie rozważań antropologicznych Gehlena w empirii ma swoje źródło w jeszcze jednym rozstrzygnięciu, które przejął on od Schelera. Ten w swoim projekcie nowej dyscypliny filozoficznej porzucił, mający długą tradycję, sposób opisu i wyjaśniania fenomenu człowieka w relacji do Boga-Stworzyciela, zastępując go analizą porównawczą człowieka i zwierzęcia. Tak zakreślone ,pole badawcze z życiem zwierzęcym w tle” umożliwiło mu wprowadzenie szerokiej sfery zjawisk biologicznych, będących domeną nauk szczegółowych (zoologii, fizjologii, anatomii itp.), do przedmiotu rozważań antropologii filozoficznej. Taka zmiana podejścia do tematu jest - zdaniem Gehlena - nie tylko prawomocna, ale wręcz konieczna, jeśli pragnie się, aby wielowiekowe, filozoficzne dociekania nad człowiekiem zwieńczyły wreszcie przekonujące rezultaty. 


\section{Czlowiek jako Mängelwesen}

W punkcie wyjścia swoich rozważań Gehlen wyraźne nawiązuje do poglądów Johanna Gottfrieda Herdera i Friedricha Nietzschego. Tak jak oni podkreśla, że człowiek jako istota żywa, mająca ciało, rozpatrywana z punktu widzenia fizjologiczno-morfologicznego, w przeciwieństwie do wszystkich wyższych ssaków, jest charakteryzowany głównie negatywnie poprzez swoje braki (Mängel). Polegają one przede wszystkim na niedostosowaniu, niewyspecjalizowaniu i swoistym prymitywizmie (zob. [Gehlen 1962, s. 33]).

Niedostosowanie oznacza, że człowiek nie posiada naturalnej osłony przed niekorzystnymi warunkami klimatycznymi (gruba skóra, gęste owłosienie całego ciała) oraz naturalnych narządów ataku (kły, pazury, rogi), obrony (naturalny pancerz, trujące wydzieliny) lub ucieczki (wrodzona szybkość), brakuje mu instynktów, dysponuje słabymi zmysłami, niska jest też jego ogólna sprawność fizyczna.

Niewyspecjalizowanie polega na braku naturalnego przystosowania człowieka do określonego środowiska. Organizmy zwierzęce są perfekcyjnie „dopasowane” do otoczenia, tworzą pewnego rodzaju zespoloną z nim całość. Tymczasem człowiek, z punktu widzenia morfologii, stanowi przypadek wyjątkowy. W każdym środowisku, w każdym otoczeniu jest on „nie u siebie”.

Te dwa punkty biologicznej charakterystyki człowieka zostały podniesione najpierw przez Herdera, który był pomysłodawcą idei Mängelwesen ${ }^{3}$, następnie zaś przez Nietzschego, który w tym celu posłużył się równie nośnym pojęciem, określając człowieka jako „nie ustalone zwierzę” (nicht festgestellte Tier). Gehlen znacznie wzbogacił ten opis, odwołując się do najnowszych osiągnięć anatomii porównawczej kręgowców i teorii ewolucji człowieka.

Twórcą teorii, która pewne cechy budowy ludzkiej ujmuje jako oznaki „prymitywności” („niedorozwinięcia”) był holenderski anatom Ludowijk Bolk (1866-1930). Gehlen [2001, s. 79] streszcza i interpretuje ją następująco:

Rozumie się przez to, po pierwsze, że pewne szczególne cechy narządów, jak pełny zgryz, pięciopalcowa ręka, i inne, muszą być „,archaiczne”, tzn. historycznie dawne, że są zrozumiałe tylko jako punkt wyjścia specjalizacji, które znajdziemy u małp człekokształtnych (wydatny kieł, krótszy kciuk); a po drugie, że dalsze cechy szczególne (brak uwłosienia, sklepienie czaszki z nisko osadzonym uzębieniem, budowa miednicy itp.) należy rozumieć jako zatrzymane, utrwalone stany rozwoju płodowego. Ta „retardacja”, której człowiek zawdzięcza swój jakby

${ }^{3}$ Herder nie posługiwał się w swojej pracy, upowszechnionym dopiero przez Gehlena, terminem Mängelwesen (,istota ułomna”, „,istota naznaczona brakiem”). Jednak, jak podkreśla sam Gehlen, to właśnie Herder jako pierwszy przedstawił i naukowo uzasadnił koncepcję człowieka jako istoty, która wyraźnie ustępuje zwierzętom pod względem biologicznym. 
embrionalny habitus, jest niezwykle wartościową zasadą wyjaśniania, ponieważ pozwala zrozumieć inne jeszcze swoiste cechy człowieka, a zwłaszcza nieproporcjonalnie wydłużony okres rozwoju, długi czas nieporadności w fazie dziecięcej, późną dojrzałość płciową.

Wymienione „braki” i „prymitywizmy” stanowią - według Gehlena - „usprawiedliwienie opisowego i porównawczego przeciwstawienia człowieka i zwierzęcia, a zwłaszcza człowieka i jego najbliższych krewnych, wysoko wyspecjalizowanych małp człekokształtnych" [Gehlen 2001, s. 79].

Wnioski, które płyną z tego przeciwstawienia są dosyć oczywiste. Człowiek jako „istota naznaczona brakiem” z góry skazany jest na porażkę. Powinien dawno już zniknąć z powierzchni Ziemi, przegrywając z kretesem walkę o przetrwanie. Tak się jednak nie stało. Odpowiedź na pytanie „dlaczego” jest właśnie zadaniem filozofii.

\section{Człowiek jako istota działająca}

Próbując uporać się z tak sformułowanym problemem, Gehlen wykorzystuje strategię, którą kiedyś z sukcesem zastosował Immanuel Kant. Filozof z Królewca uznał za bezprzedmiotową dyskusję, czy istnieją sądy, które są konieczne (a priori) i zarazem poszerzają naszą wiedzę (syntetyczne). Sądy takie są domeną matematyki i matematycznego przyrodoznawstwa. W tej sytuacji według Kanta - ważne jest tylko jedno pytanie: jak są możliwe sądy syntetyczne a priori?

Gehlen również nie widzi powodów, aby zagłębiać się w rozważania, czy zwierzęta są pod względem biologicznym lepiej od człowieka przygotowane do walki o przetrwanie. Biologiczne ,upośledzenie” człowieka jest faktem (Mängelwesen). Znacznie ważniejsza jest odpowiedź na pytanie, jakie warunki musiały zostać spełnione, aby istota taka jak człowiek mogła zachować istnienie.

Gehlen zwraca uwagę na zasadniczą różnicę w sposobie funkcjonowania zwierząt i człowieka. Zwierzęta są związane z właściwym dla danego gatunku środowiskiem. W tym kręgu zachowują się z wrodzoną bezbłędnością, z instynktowną pewnością. Można powiedzieć, że są one w pełni wyposażonymi, ,przemyślanymi”, skończonymi dziełami Natury. Człowiek jest pozbawiony tych atutów. „Zdany na surową przyrodę jak zwierzę, przy wrodzonej mu konstrukcji fizycznej i niedostatku instynktów, nie byłby w żadnym razie zdolny do życia" [Gehlen 2001, s. 37]. W tej sytuacji możliwe jest tylko jedno wyjście: człowiek nie może, tak jak zwierzęta, po prostu żyć, lecz musi on „prowadzić swoje życie”, tzn. dokonywać ważnych życiowo wyborów, zajmować stanowisko wobec siebie 
i otaczającego go świata. Mówiąc inaczej, człowiek musi kompensować swoje naturalne braki działaniem.

Pojęcie działania (Handlung) ${ }^{4}$ odgrywa ważną rolę w antropologii Gehlena. Rozumiane jest ono jako ,aktywność zmierzająca do zmiany przyrody na użytek człowieka" [Gehlen 2001, s. 36]. Jedną z kluczowych form tej aktywności jest próba zrozumienia siebie i określenia zadań, jakie stoją przed człowiekiem. Wyjaśnienia dotyczące bytu ludzkiego nie mają przy tym czysto teoretycznego charakteru, nie służą wyłącznie zaspokojeniu ciekawości badacza, lecz spełniają ważną funkcję życiową - stosownie do rozstrzygnięć, które zawierają, umożliwiają one dokonywanie optymalnych $-\mathrm{z}$ punktu widzenia celu - wyborów. Wychodząc od tak rozumianego „działania” i jego materialnych uwarunkowań, można dopiero - według Gehlena - próbować zrozumieć specyficzne ludzkie dokonania i właściwości.

"Istota o takich cechach organicznych - stwierdza Gehlen - jest zdolna do życia tylko dzięki przewidującemu zmienianiu przyrody" [Gehlen 2001, s. 82]. Jej aktywność natrafia jednak na zasadniczą przeszkodę. Nie dysponuje ona żadnym gotowym i sprawdzonym planem działania. Człowiek - jak podkreśla Gehlen - jest ,niepowtarzalnym, nigdy jeszcze niewypróbowanym projektem natury" [Gehlen 1962, s. 14]. W tej sytuacji dokonywane przez niego wybory są obciążone ryzykiem, nie można bowiem w pełni przewidzieć ich konsekwencji. Nie ma jednak zbyt wiele miejsca na błąd, gdyż chodzi o przetrwanie.

Brak właściwego zwierzętom dopasowania do środowiska wpływa na funkcjonowanie człowieka w innym jeszcze aspekcie. Zwrócił na to uwagę już Scheler w swojej koncepcji człowieka jako istoty, w sposób fundamentalny, „otwartej na świat”. W antropologii Gehlena, zgodnie z koncepcją że „dowolne różnorodne czynniki świata zewnętrznego mogą wywierać na człowieka wpływ także wtedy, gdy są biologicznie obojętne lub nawet szkodliwe" [Gehlen 2001, s. 36], nabrała ona dodatkowego znaczenia, dzięki powiązaniu jej z ideą działania.

Ludzka „otwartość na świat”, w końcowym efekcie, okazała się cenną, sprzyjającą sukcesowi gatunku ludzkiego, właściwością. Pod względem biologicznym oznacza ona jednak negatywny stan rzeczy. Zwierzęta oceniane pod względem przygotowania do walki o przetrwanie są perfekcyjnymi tworami natury. Nie zwracają one uwagi na to, co nie jest przez nie odbierane jako wróg, potencjalna zdobycz, pożywienie, czy też oznaka płci. Selekcja bodźców dotyczy w ich wypadku wszystkich biologicznie zbędnych treści. Tymczasem człowiek jako Mängelwesen, jako istota „otwarta na świat” już od poziomu życia popędowego, „wystawiony jest na zalew bodźców, na bogactwo danych postrzeżeniowych”, zarówno tych, które są życiowo ważne, jak i (w większości) tych, które z biolo-

${ }^{4}$ Pojęcie to - jak sam przyznaje - zaczerpnął Gehlen od amerykańskich pragmatystów, w głównej mierze od Johna Deweya [1922]. 
gicznego punktu widzenia są nieistotne. Naturalne wyposażenie nie chroni człowieka przed nawałnicą bodźców, których źródłem jest przyroda. Aby przetrwał, niezbędne jest odciążenie (Entlastung), stworzenie środowiska, które będzie mu przyjazne. Człowiek musi zatem ustanowić swój własny świat - świat kultury. Jest to sztucznie przystosowany świat zastępczy uwzględniający zawodność organicznego wyposażenia człowieka, swoista „,druga natura”. Sztucznie oczyszczona, ,uporęczniona" przyroda, zmieniona tak, by służyła człowiekowi - to właśnie jest sfera kultury (zob. [Gehlen 2001, s. 81; Gehlen 1962, s. 37]).

\section{Człowiek jako twórca kultury}

Kultura odgrywa podstawową rolę w walce człowieka o przetrwanie. Można nawet powiedzieć, że - w ujęciu Gehlena - ma ona znaczenie przede wszystkim biologiczne. Gehlen określa ją jako „sumę czynnie zmienionych pierwotnych warunków, w których człowiek żyje i żyć może [Gehlen 2001, s. 80].

W zbudowanym od podstaw świecie norm i wartości, który jest swego rodzaju „sztuczną", dostosowaną do braków człowieka naturą, wreszcie czuje się on bezpiecznie i swobodnie. „Kultura ludzka - jak podkreśla Gehlen [2001, s. 43] jest w istocie stwarzaniem porządku i stabilizowaniem". Odciąża ona człowieka od zalewu bodźców, dostarczając mu instrukcji działania w postaci prawa, moralności, zwyczajów, rytuałów i instytucji. Pełni ona rolę podobną do instynktów u zwierząt, jednak czyni to w sposób bardziej elastyczny i efektywny. Tę ważną kwestię Gehlen [2001, s. 109] opisuje następująco:

Dla jednostki takie instytucje jak prawo, małżeństwo, własność itp. stanowią odciążenie od podejmowania podstawowych decyzji oraz oznaczają nawykową pewność miarodajnych orientacji, w związku z czym zachowanie jest bezrefleksyjne i stałe, może przebiegać podobnie w odmiennych sytuacjach. Instytucjonalnie regulowane zachowanie (odczuwanie, myślenie, wartościowanie) trzeba zatem pojmować jako przywrócenie utraconej zwierzęcej pewności instynktu na wyższej płaszczyźnie.

„Odciążona” od poszukiwania właściwych form zachowania jednostka zyskuje wolny czas i oszczędza energię, którą może wykorzystać do tworzenia wspólnoty i rozwijania podtrzymujących ją wyobrażeń o świecie. Kluczową rolę w tym procesie odgrywa język. Według Gehlena ma on charakter witalny, rozwija się w procesie konfrontacji ludzkiego życia z akustycznymi i optycznymi bodźcami świata zewnętrznego. Język, dzięki symbolom, umożliwia swobodne „dysponowanie" rzeczami, ogarnięcie myślami przeszłości, przyszłości oraz tego, co nieobecne. Uniezależnienie się człowieka „od Tu i Teraz”, szerokie otwarcie 
się na świat sprawia, że „zostaje przełamany zaklęty krąg bezpośredniości, w którym zawsze zamknięte jest zwierzę" [Gehlen 2001, s. 88].

Równie ważnym, jak stosunek słowa do rzeczy, aspektem języka jest jego funkcja jako środka przekazu i porozumiewania się. Ona również prowadzi do odciążenia człowieka i zwiększenia stopnia pośredniości zachowań wobec świata. Działania jednostki nie są już wyłącznie konsekwencją pobudek mających swoje źródło w jej świecie wewnętrznym, lecz w równym stopniu są one wynikiem czyichś wyobrażeń, rad lub rozkazów.

Sprawnie funkcjonująca dzięki językowi wspólnota nie opiera się tylko na bieżących osiągnięciach i dokonaniach poszczególnych jednostek. Język pozwala przełamać ograniczenia przestrzenne i czasowe. Sprawia, że gatunek ludzki nie musi budować zrębów swojej kulturowej egzystencji w każdym pokoleniu od podstaw, lecz może korzystać z dorobku poprzedników, dodając do niego tylko rezultaty własnej aktywności. Język jest więc bez wątpienia najwyższym osiągnięciem człowieka.

Człowiek jako Mängelwesen dysponuje ograniczonym zasobem wrodzonych i stereotypowych form zachowania. W wyniku rozwoju kultury ich znaczenie jeszcze się zmniejsza. Ograniczeniu ulega również bezpośredni wpływ sił popędowych na człowieka. Ich ilość jednak się nie zmienia. Rozwijają się wewnątrz i szukają innych, dozwolonych w ramach danej kultury, form wyrazu. Zagadnieniem tym zajmował się już Nietzsche w swojej koncepcji sublimacji popędów, wiele miejsca poświęcił mu Carl Gustav Jung, wprowadzając pojęcie libido dla oznaczenia rezerwuaru wszystkich sił popędowych człowieka, o „nadmiarze popędów" pisał również Scheler. Gehlen odwołuje się do ich dokonań, koncentrując się na problemie relacji między szukającymi ujścia siłami popędowymi a kulturą. „Obyczaje, nawyki prawne i instytucje danego społeczeństwa tworzą gramatykę, której reguły muszą respektować nasze siły popędowe" [Gehlen 2001, s. 101]. Instytucje te działają zatem ,jak śluza, która pewne siły popędowe kanalizuje, a pewne tłumi”. Sprawność i niezawodność ich funkcjonowania daje o sobie znać w różnych sferach egzystencji człowieka. Ma ona bowiem wpływ na wielkość i charakter osiągnięć gatunku ludzkiego, na jego bezpieczeństwo, a nawet (w ostateczności) na możliwość przetrwania człowieka.

Główną rolę w stabilizowaniu życia społecznego odgrywa moralność. „Jej sens polega na tym, by gwarantować bezpieczeństwo i na podstawie wzajemnego zaufania nie dopuszczać do zakłóceń w zachowaniach" [Gehlen 2001, s. 44]. Sama w sobie, bez wsparcia ze strony funkcjonujących w społeczeństwie instytucji, nie mogłaby jednak skutecznie pełnić swojej roli. Prawo, style zachowań, „utarte formy współdziałania występujące jako porządki gospodarcze, socjalne i religijne, funkcjonują jako zewnętrzne wsporniki, jako mocne ogniwa łączące 
ludzi" [Gehlen 2001, s. 45], budując przez to zaufanie do moralności i gwarantując społeczną stabilność.

\section{Czlowiek a tradycja}

A. Gehlen podkreśla znaczenie ciągłości i trwałości stworzonych przez człowieka instytucji. Przyznaje wprawdzie, że cała ludzka historia świadczy o ich zmienności, widzi jednak potrzebę ich obrony i stabilizacji.

Jeśli instytucje danego narodu ulegną zniszczeniu, to wówczas w człowieku wyzwala się elementarna niepewność, skłonność do zwyrodnienia i chaosu [Gehlen 2001, s. 45].

Wygląda na to, że w elemencie „tradycja” tkwi coś niezbywalnego dla naszego wewnętrznego zdrowia [...]. W tradycji zachowań, wartościowania i obowiązywania - po długim okresie eksperymentów - położono wreszcie fundamenty, których nie należy ustawicznie kwestionować, które nie domagają się żadnych decyzji, bo stają się przyzwyczajeniem [Gehlen 2001, s. 104].

Warto odnotować, że w obronie tradycji Gehlen odwołuje się nawet do głosiciela idei wolności i arystokratycznego indywidualizmu - Friedricha Nietzschego, który twierdził, że „wysoka kultura wymaga, by wiele rzeczy pozostawić bez wyjaśnienia. Wymaga ona zatem tradycji, które nie deklarują się za czymś lub przeciw czemuś, ale są respektowane dzięki obowiązywaniu tego, co zawsze było [...]. Tylko na bazie tego, co oczywiste, co stało się nawykiem oraz nie podlega krytyce i kontroli, można „sublimować”, można improwizować wyrafinowane rozwiązania lub z pełną świadomością wagi i ryzyka podejmować duchowy i moralny eksperyment" (cyt. za: [Gehlen 2001, s. 104]).

Nasze czasy określa Gehlen jako „tradycjożercze”. Nieustannie dokonuje się kulturowych eksperymentów, podważa się sprawdzone instytucje, wynajduje się rozwiązania aktualne tylko w momencie wprowadzania ich w życie. Przyczyny tego są złożone. Mogą one mieć swoje źródło w nieodpowiedzialnych działaniach jednostek, przemijających modach i tendencjach, ale mogą one też być konsekwencją immanentnej niestabilności o innym podłożu. Interesującą próbę wyjaśnienia tego zjawiska - do której z uwagą odnosi się Gehlen - podjął wybitny etolog, twórca teorii domestyfikacji - Konrad Lorenz (1903-1989).

Zdaniem Lorenza istnieje analogia między zmianami, którym podlegają udomowione zwierzęta, jak i cywilizowani ludzie. Rygory narzucone zwierzętom domowym (ograniczenie swobody poruszania się, utrudniony dostęp do słońca i światła, wyłączenie naturalnej selekcji itd.) prowadzą do utraty sprawności fizycznej, niechęci do ruchu i (przede wszystkim) dysharmonii instynktów. Tego rodzaju ograniczenia dotykają również cywilizowanego człowieka. Podobne 
są też ich skutki: w porównaniu do swoich dzikich przodków jest on fizycznie słabszy, porusza się niewiele, zaś jego instynkty cechuje coraz bardziej pogłębiające się rozprzężenie. U wszystkich udomowionych istot wzrasta ilościowo popęd głodu i popęd płciowy, coraz słabsze zaś są zahamowania. Wraz z postępem cywilizacji - według Lorenza - następuje rozkład lub wyraźne rozluźnienie norm moralnych i tradycyjnych reguł zachowania.

Teoria Lorenza szybko stała się popularna i zyskała zwolenników zarówno wśród naukowców, jak i filozofów. Gehlen kwestionuje jednak jej przesłanki, jak i wyprowadzone wnioski. Lorenz zakładał, że praczłowiek w swojej „,dzikiej formie podlegał tym samym, wysoko wyspecjalizowanym i zróżnicowanym regulacjom instynktów" [Gehlen 2001, s. 96], których istnienie wykazał u wielu gatunków dzikich zwierząt. Obserwując zaś u zwierząt domowych rozkład tych regulacji, doszedł do wniosku, że analogiczny proces zachodzi w społeczności ludzkiej, ponieważ człowiek udomowił też samego siebie. Zdaniem Gehlena nie ma jednak dowodów na to, aby praczłowiek podlegał tym samym wysoko wyspecjalizowanym i zróżnicowanym regulacjom instynktów, co jego zwierzęcy pobratymcy. Wiemy natomiast, że pierwsze hominidy sprzed trzech milionów lat z grupy australopiteków praktykowały kanibalizm, podobnie sinantropus sprzed pięciuset tysięcy lat, jak i niektóre prymitywne plemiona już w epoce nowożytnej. Równie długa jest historia narkotyków i środków odurzających. Teza Gehlena [2001, s. 96] jest zatem następująca: „plastyczność i skłonność do wyrodnienia życia popędowego ma u człowieka charakter jawnie pierwotny, a nie wtórny".

Dzięki wielu próbom, dzięki wysiłkom kolejnych pokoleń, wypracowano określone formy regulowania i ograniczania wewnętrznej niestabilności ludzkich sił popędowych, takie jak: prawo, monogamiczna rodzina, określony podział pracy, własność itd. To właśnie one - zdaniem Gehlena - utrzymują w ryzach nasze życie popędowe.

Instytucje te nie są w żadnym razie czymś naturalnym i ulegają bardzo szybkiemu zniszczeniu [...]. Jeśli te podpory zostają usunięte, to cofamy się w rozwoju w bardzo szybkim tempie [Gehlen 2001, s. 97].

Należy w tym miejscu podkreślić, że Gehlen bynajmniej nie opowiadał się za uświęceniem przeszłości. W sprawach społecznych był umiarkowanym konserwatystą, a nie tradycjonalistą. Zdawał sobie sprawę z tego, że przemiany społeczne są konieczne. Przestrzegał jednak przed niedocenianiem konsekwencji różnego rodzaju utopii, romantycznych idei, destrukcyjnych działań i rewolucyjnych ruchów. Trwałość instytucji i systemów społecznych jest bowiem - z obiektywnych powodów - bardzo krucha.

[...] w toku niszczenia instytucji następuje coś w rodzaju nawrotu kierowania się instynktem. Wybuch „straszliwej naturalności”, wtedy obserwowany, odsłania 
fundamentalną ludzką niepewność i skłonność życia popędowego do degenerowania się [Gehlen 2001, s. 110] ${ }^{5}$.

Ruchy prowadzące do rozpadu są zawsze naturalne i prawdopodobne, ruchy ku wielkości, wysokim aspiracjom i wartościom kategorycznym są zawsze wymuszone, mozolne i nieprawdopodobne. Chaos, naturalny, trzeba zakładać tak, jak to czynią najdawniejsze mity; kosmos jest boski i zagrożony [Gehlen 2001, s. 97-98].

Nadszedł już czas - twierdzi Gehlen - dla jakiegoś anty-Rousseau. Hasło „powrotu do natury” sugerujące, że kultura wypacza człowieka, zaś stan naturalny to stan sprawiedliwości, harmonii i wolności, należy zastąpić hasłem „powrotu do kultury”, bo stan natury w człowieku jest w rzeczywistości chaosem, dopiero kultura niesie z sobą prawo, obyczaje i hegemonię wartości moralnych (zob. [Gehlen 2001, s. 98]).

\section{Czlowiek jako monistyczny system}

Gehlen buduje swoją antropologię elementarną nie tylko poprzez nawiązanie do odkryć i poglądów głoszonych przez poprzedników, lecz także krytyczne odniesienie się do niektórych ujęć i koncepcji człowieka, które nie spełniają wiązanych z nimi nadziei. Słabość religijnych, naukowych lub światopoglądowych koncepcji człowieka polega - jego zdaniem - na tym, że nie udzielają one odpowiedzi na pytanie o istotę człowieka. Zazwyczaj jednak zawierają pewne założenia, na podstawie których można się pokusić o taką odpowiedź. Proponowane wyjaśnienia wykluczają się jednak wzajemnie (zob. [Gehlen 1962, s. 9]). Obecnie największym uznaniem cieszą się dwie koncepcje człowieka: teologiczna i przyrodnicza. Pierwsza z nich uznaje człowieka za dzieło Boga Stworzyciela, druga - wyprowadza go ze świata zwierząt. Koncepcja teologiczna nie jest naukowa, koncepcja przyrodnicza - według Gehlena - jest naukowo dwuznaczna. Łączy je wspólne założenie (odrzucane przez Gehlena): człowieka nie da się opisać i zrozumieć, odwołując się do jego immanentnych własności (aus sich selbst), lecz tylko za pomocą kategorii wobec niego zewnętrznych, wykraczających poza to, co ludzkie. Gehlen przyjmuje, że powyższe założenie jest nieuzasadnione, gdyż możliwe jest ujęcie człowieka za pomocą specyficznych i odnoszących się tylko do niego kategorii. Główne z nich to: Mängelwesen, działanie, istota zajmująca stanowisko, istota otwarta na świat, odciążenie, kultura, język, tradycja.

5 Teza ta - jak podkreśla Gehlen [2001, s. 110] - „,należy do podstawowych zasad realistycznej antropologii, czyli w istocie antropologii, która nie zachowuje się niefrasobliwie”. 
Należy podkreślić, że w koncepcji Gehlena żadna z tych kategorii nie ma monopolu na wyjaśnienie specyfiki człowieka. Tym samym odżegnuje się on od rozpowszechnionych ujęć człowieka, które koncentrują swoją uwagę na jednym jego atrybucie, czy też próbują sprowadzić jego istotę do jednej właściwości. A zatem nie animal rationale, animal religiosum, homo faber, homo ludens, czy też homo oeconomicus, lecz pewna całość, system powiązanych ze sobą równorzędnych czynników, który należy opisywać w sposób inny niż do tej pory czyniono $^{6}$.

Gehlen odrzuca też powszechnie stosowane w filozofii i nauce wyjaśnianie przyczynowe. Pojęcie „przyczyna” ma definicyjny sens tylko tam, gdzie poszczególne związki można wyizolować, czyli w ramach czysto eksperymentalnych nauk. W innych obszarach refleksji „metafizyka jednej przyczyny” musi być zastąpiona przez bardziej uzasadnione, kompleksowe ujęcie. W antropologii elementarnej Gehlena mowa jest zatem o strukturze warunków ludzkiego życia, która ma postać następującą: bez A nie ma B, bez B nie ma C, bez $\mathrm{C}$ nie ma $\mathrm{D}$ itd. Jeśli ostatni element tego szeregu wróci do pierwszego - bez $\mathrm{N}$ nie ma $\mathrm{A}$ - wtedy - zdaniem Gehlena [1962, s. 18] - otrzymujemy obraz, który całościowo ujmuje zjawisko „człowiek”.

Niepowodzenia wcześniejszych prób zbudowania spójnej koncepcji człowieka wiążą się - zdaniem Gehlena - również z tym, że jego poprzednikom nie udało się połączyć w jedną całość wyróżnianych w człowieku sfer: ciała i duszy, „wnętrza” z tym, co „zewnętrzne”, morfologii i psychologii. Pozostały one obcymi sobie światami. Gehlen zajmuje w tej kwestii stanowisko monistyczne i jest to oczywiście monizm materialistyczny. Za pomocą wprowadzonych przez siebie kategorii (Mängelwesen, działanie, istota zajmująca stanowisko, istota otwarta na świat, odciążenie, kultura, język, tradycja) stara się on przezwyciężyć dominujący w filozofii człowieka dualizm, dąży do tego, by sprowadzić „ducha” do ,życia”, pokazuje na gruncie nauki i doświadczenie, że możliwe jest harmonijne współistnienie tych warstw.

\section{Uwagi końcowe}

Projekt antropologii elementarnej, przedstawiony przez Arnolda Gehlena, przyjęty został z dużym zainteresowaniem. W opublikowanej w 1942 r. recenzji pracy Der Mensch. Seine Natur und seine Stellung in der Welt dał temu wyraz wybitny niemiecki filozof Nicolai Hartmann: „Niczego z takim utęsknieniem nie oczekiwano w fachowych kręgach niemieckiej filozofii jak nowego, wyzna-

${ }^{6}$ Pomysł ten zaczerpnął Gehlen od J. G. Herdera. Zob. [Kusak 2012, s. 27-46]. 
czającego podwaliny punktu wyjścia antropologii filozoficznej" (cyt. za: [Paczkowska-Łagowska 1997, s. 167]).

Niektóre rozwiązania przyjęte przez Gehlena zostały jednak skrytykowane. Zarzucano mu uproszczenia w jego naturalistycznej koncepcji języka, krytykowano naturalistyczną koncepcję kultury, wytykano nadmierne przywiązanie do starej już koncepcji człowieka jako Mängelwesen ${ }^{7}$, stawiano nawet pod znakiem zapytania wiarygodność jego fundamentalnego założenia, że można filozofować przy zawieszeniu hipotez metafizycznych. W syntetyczny sposób zastrzeżenia te wyraził Walter Schultz w pracy pt. Philosophie in der veränderten Welt [1972]: „W gruncie rzeczy u Gehlena instynkt samozachowawczy pełni funkcję abstrakcyjnej zasady, na podstawie której i ze względu na którą podejmuje się interpretacje. A formułując to ostrzej: Gehlen opiera się na metafizyce biologistycznej" (cyt. za: [Haeffner 2006, s. 31]).

Z taką oceną nie wszyscy się jednak zgadzają. Elżbieta Paczkowska-Łagowska podkreśla, że stawiane przez Gehlena pytanie, choć nastawione na to, co cielesne, nie ma charakteru biologicznego, lecz antropo-biologiczny: kieruje się ono ku temu, jak musi być wyposażona istota ludzka, by zachować swoje istnienie.

Pozornie biologiczne pytanie dotyczy więc zasadniczo warunków egzystencji człowieka. Antropologia zawarta w dziele Der Mensch nie ma charakteru biologistycznego, bowiem istota ludzka zostaje w niej raczej ujęta jako konstytuująca samą siebie. Nie można jednak ignorować faktu, że do owej autokreacji dochodzi z biologicznie uzasadnionej konieczności „zachowania się przy życiu”. Ta zaś okoliczność świadczy nie o biologizmie, lecz o poszukiwaniu przez Gehlena realnych, obiektywnych podstaw zakotwiczenia ludzkiego życia [Paczkowska-Łagowska 1997, s. 168].

Sam Gehlen zdecydowanie odrzuca oskarżenia jakoby jego antropologia wpisywała się w nurt postdarwinowskich, biologizujących koncepcji człowieka. Podkreśla, że jego rozprawa jest w znacznym stopniu poświęcona polemice z „naturalistycznymi”, czy też „biologicznymi” koncepcjami człowieka, które odwołując się do nauki o pochodzeniu gatunków, wywodzą go w prostej linii ze świata zwierząt. Wydawałoby się wprawdzie, że dysponują one silnymi argumentami. Gdy bowiem spojrzymy na człowieka z zewnątrz, zapoznamy się z budową jego ciała, weźmiemy pod uwagę badania nad skamieniałościami i resztkami szkieletów dawno wymarłych istot, wniosek o zasadności teorii bezpośredniego pochodzenia człowieka od antropoidów zdaje się uprawniony. Zwolennicy biologicznej koncepcji człowieka koncentrują jednak uwagę na cielesności człowieka i prawach rozwoju organicznego życia, nie mogą zaś - na co zwraca uwagę

7 „Człowiek tylko wtedy jawi się jako istota wykazująca braki, kiedy wyposażenie zwierząt służące zwierzęcym celom, podnosi się do rangi wzorca obowiązującego również człowieka" [Haeffner 2006, s. 31]. 
Gehlen - nic powiedzieć na temat jego „wnętrza”. Umyka im problem moralności, języka, fantazji, woli, poznania i prawdy.

Gehlen w swojej antropologii próbuje uporać się z tym problemem. Przyjmuje, że człowiek jest „,niepowtarzalnym projektem” natury, który jako przedmiot poznania wymaga zastosowania specyficznego podejścia i starannie dobranych narzędzi. „Antropo-biologiczny sposób poznania” (anthropo-biologische Betrachtungsweise) - o który tutaj chodzi - pozwala uchwycić człowieka jako całość, czyli ująć szczególne, cielesne właściwości człowieka w ich związkach z bardzo skomplikowanym „wnętrzem” za pomocą dostosowanych do tego zagadnienia kategorii (zob. [Gehlen 1962, s. 14-15]).

Przedstawiony zarys dyskusji poświęconej antropologii elementarnej Arnolda Gehlena ma charakter wstępny i nie wyczerpuje długiej listy pytań i wątpliwości. Wydaje się jednak, że w zestawieniu zalet i wad, pozytywnych i negatywnych ocen koncepcji Gehlena, zdecydowanie przeważają te pierwsze.

Niemiecki filozof przedstawił całościową koncepcję człowieka, rzucając przy tym światło na wiele szczegółowych obszarów jego egzystencji, które z różnych powodów nie doczekały się wcześniej racjonalnej i wiarygodnej interpretacji. Koncepcja ta łączy biologiczne i kulturoznawcze widzenie człowieka. Jest bliska doświadczeniu i otwarta na nowe wyniki badań ${ }^{8}$. Pozytywnie wyróżnia się ona na tle dominujących współcześnie, uproszczonych, hedonistycznych i utylitarystycznych koncepcji człowieka.

\section{Literatura}

Dewey J. [1922], Human Nature and Conduct, New York.

Gehlen A. [1962], Der Mensch. Seine Natur und seine Stellung in der Welt, wyd. 17, Athenäum Verlag, Frankfurt a. Main/Bonn.

Gehlen A. [2001], W kręgu antropologii i psychologii spolecznej, thum. K. Krzemieniowa, Czytelnik, Warszawa.

Haeffner G. [2006], Wprowadzenie do antropologii filozoficznej, tłum. W. Szymona OP, Wydawnictwo WAM, Kraków.

Kusak L. [2012], Johanna Gottfrieda Herdera koncepcja człowieka, „Zeszyty Naukowe Uniwersytetu Ekonomicznego w Krakowie", nr 882.

Paczkowska-Łagowska E. [1997], Der Mensch [w:] Przewodnik po literaturze filozoficz$n e j$, red. B. Skarga, Wydawnictwo Naukowe PWN, Warszawa.

${ }^{8}$ Współpraca z nauką jest jednym z kluczowych założeń antropologii elementarnej Gehlena. Ważnym jej elementem jest wykorzystywanie faktów nauk szczegółowych w procesie formułowania i weryfikacji antropologicznych tez. Warto więc podkreślić, że, szczególnie w tym drugim aspekcie, koncepcja Gehlena wielokrotnie wykazywała zgodność z najnowszymi wynikami badań w naukach szczegółowych (zob. [Gehlen 2001, s. 78]). 


\section{The Elementary Anthropology of Arnold Gehlen}

(Abstract)

Of a historical and comparative character, this article's basic aim is to reconstruct the main principles of the somewhat forgotten philosophical anthropology of Arnold Gehlen. Some of the principles were derived from the works of J. G. Herder (man as Mängelwesen), F. Nietzsche (man as nicht festgestellte Tier), and M. Scheler (man's "openness" to the world). The majority of the proposed theses, however, were Gehlen's own (the idea of "unburdening", man as Kulturwesen, tradition as a life-stabilising force). Apart from its strengths, Gehlen's anthropology has some weaknesses (biologistic metaphysics, attaching excessive significance to the outdated conception of "a deficient being", blurring the boundaries between the philosophical method and the scientific method). They are the subject of discussions carried out both by scientists conducting empirical research on man and by experts on the philosophy of man, as well as being the subject of my own interest.

Keywords: Mängelwesen, action, "openness" to the world, "unburdening", culture, tradition. 